\title{
Chopin Twenty-four Preludes In No.1 in C Major; No.2 in A Minor; No.3 in E Minor
}

\author{
Ma Ting \\ Jingzhong Normal Junior College, Jinzhong, Shanxi, China \\ International College, Krirk University, Bang Khen District, Bangkok, Thailand
}

Keywords: Prelude, harmony, tune structure, compositional technique

Abstract: Chopin, the great Polish composer and "piano poet", produced many piano works during the Romantic Period in Europe. Twenty-four Preludes (op. 28) are called "the universe of the Bagatelle music" since Chopin's preludes played a role in linking the past and the future, and Bach can be seen in Chopin's preludes played a role in linking the past and the future, and Bach can be seen in the Twenty-four Preludes, while in Debussy and Rachmaninoff's preludes, you can see the reflection of Chopin's musical form. This article analyses the harmony, composition and technique of the Twenty-fourPreludes-No.1 in C Major; No.2 in A Minor; No.4 in E Minor, devoting further studies to the charm of Chopin's music.

\section{Introduction}

Chopin (Frederic Francois Chopin 1810-1849), the most famous Polish musician, is affectionately known as the "Piano Poet" and one of the few composers who concentrated his work on the piano.His compositions can be said to cover all genres of the piano, with the Op. 28 "Twenty-four Preludes" completed between about 1831 and 1839. The "universe of miniatures" for piano is a summary of Chopin's preludes by James Huneker, a summary that is recognized by many scholars and music lovers. Because it captures the character of the work directly and accurately. The preludes of Chopin's time were no longer "introductions" or preparatory to larger works. Each of his preludes stands on its own, and although Chopin was not the first to make them independent, he was always at the forefront. Yusuf. Hominsky, in his article "The Problem of Form in Chopin's Preludes," refers to "raising the form of the prelude to a pinnacle of perfection that none of his successors have been able to surpass."

\section{Tune structure}

The Twenty-four Preludes are based on Twenty-four major and minor keys in 12-mean meter, each corresponding to a key according to the cycle of fifths, short and concise, each with its own character, like Twenty-four small poems in very different styles. Except for the 17th piece, which has a rondo structure, the entire set is in a relatively regular one-movement, single-two, single-three structure. The majority of these are in the one-movement structure, as shown in Table 1. 
Table 1: Summary of the structure of Chopin's Twenty-four Preludes

\begin{tabular}{|c|c|c|c|c|c|c|c|c|}
\hline \multicolumn{9}{|c|}{ Chopin's Twenty-four Preludes } \\
\hline $\begin{array}{c}1 \text { st } \\
\text { song }\end{array}$ & $\begin{array}{c}\mathrm{C} \\
\text { major }\end{array}$ & $\begin{array}{l}\text { one-part } \\
\text { series }\end{array}$ & No. 9 & $\begin{array}{c}\mathrm{E} \\
\text { major }\end{array}$ & $\begin{array}{l}\text { one-part } \\
\text { series }\end{array}$ & Song 17 & $\begin{array}{l}\mathrm{bA} \\
\text { major }\end{array}$ & $\begin{array}{l}\text { roundabout } \\
\text { (music) }\end{array}$ \\
\hline $\begin{array}{l}\text { 2nd } \\
\text { song }\end{array}$ & a minor & $\begin{array}{l}\text { one-part } \\
\text { series }\end{array}$ & Song 10 & $\begin{array}{l}\text { \#c } \\
\text { minor }\end{array}$ & $\begin{array}{l}\text { one-part } \\
\text { series }\end{array}$ & Song 18 & f minor & $\begin{array}{l}\text { one-part } \\
\text { series }\end{array}$ \\
\hline $\begin{array}{l}\text { 3rd } \\
\text { song }\end{array}$ & $\begin{array}{c}\mathrm{G} \\
\text { major }\end{array}$ & $\begin{array}{c}\text { one-part } \\
\text { series }\end{array}$ & Song 11 & $\begin{array}{c}\mathrm{B} \\
\text { major }\end{array}$ & $\begin{array}{c}\text { one-part } \\
\text { series }\end{array}$ & Song 19 & $\begin{array}{c}\mathrm{bE} \\
\text { major }\end{array}$ & $\begin{array}{l}\text { Reproduction } \\
\text { of single } \\
\text { three }\end{array}$ \\
\hline Song 4 & e minor & $\begin{array}{l}\text { one-part } \\
\text { series }\end{array}$ & Song 12 & $\begin{array}{l}\# g \\
\text { minor }\end{array}$ & $\begin{array}{l}\text { Reproduction } \\
\text { of } \quad \text { single } \\
\text { three }\end{array}$ & Song 20 & c minor & $\begin{array}{l}\text { one-part } \\
\text { series }\end{array}$ \\
\hline $\begin{array}{l}\text { 5th } \\
\text { song }\end{array}$ & $\begin{array}{l}\mathrm{D} \\
\text { major }\end{array}$ & $\begin{array}{l}\text { one-part } \\
\text { series }\end{array}$ & Song 13 & $\begin{array}{l}\# \mathrm{~F} \\
\text { major }\end{array}$ & $\begin{array}{l}\text { reproduce } \\
\text { single two }\end{array}$ & Song 21 & $\begin{array}{l}\mathrm{bB} \\
\text { major }\end{array}$ & $\begin{array}{l}\text { Reproduction } \\
\text { of } \\
\text { three }\end{array}$ \\
\hline Song 6 & b minor & $\begin{array}{l}\text { one-part } \\
\text { series }\end{array}$ & Song 14 & $\begin{array}{l}\text { be } \\
\text { minor }\end{array}$ & $\begin{array}{l}\text { one-part } \\
\text { series }\end{array}$ & Song 22 & g minor & $\begin{array}{l}\text { bipartite } \\
\text { song }\end{array}$ \\
\hline No. 7 & $\begin{array}{l}\text { A } \\
\text { major }\end{array}$ & $\begin{array}{l}\text { one-part } \\
\text { series }\end{array}$ & Song 15 & $\begin{array}{l}\text { bD } \\
\text { major }\end{array}$ & $\begin{array}{l}\text { Reproduction } \\
\text { of single } \\
\text { three }\end{array}$ & Song 23 & F major & $\begin{array}{l}\text { one-part } \\
\text { series }\end{array}$ \\
\hline Song 8 & $\begin{array}{l}\mathrm{ff} \\
\text { minor }\end{array}$ & $\begin{array}{l}\text { Reproduction } \\
\text { of } \quad \text { single } \\
\text { three }\end{array}$ & No. 16 & $\begin{array}{l}\mathrm{bb} \\
\text { minor }\end{array}$ & $\begin{array}{l}\text { one-part } \\
\text { series }\end{array}$ & Song 24 & d minor & $\begin{array}{l}\text { Reproduction } \\
\text { of } \quad \text { single } \\
\text { three }\end{array}$ \\
\hline
\end{tabular}

The first Prelude in $\mathrm{C}$ major is a non-square integral one piece form, with a two-movement phrase structure $(8+16)$ plus a coda $(10)$ (Form 2), and a complementary terminating coda with a phrase structure. The tempo is interesting, with the choice of $2 / 8$ time. The tempo is relatively fast throughout, with a sadness tinged with anger, a tense rhythm, a thematic motive running throughout the piece, and triplets and syncopated rhythms, a rhythmic combination that gives the piece a constant impetus. The second, Prelude in A minor, is a non-square whole-part form with a three-movement phrase structure (Form 3) with an introduction (2 introductions $+5+6+10$ ), chosen in 2/2 time. There is a clear contrast between the whole piece and the first, with a slower tempo, a melody that conjures up images of sadness and hesitation, and a darker undertone in a minor key. The fourth, Prelude in e minor, is a tune with a parallel two-movement phrase structure $(12+13)$ (Form 4). The choice is in 2/2 time, with a wide tempo, and the right-hand melody is set against a left-hand column chord that speaks songfully of thoughts of the fatherland, as if seeing the post-war scenes in Poland, with pining helplessness and a bit of starry longing, a work with the air of romantic fantasy.

Form 1: Prelude in C major tune structure.

\begin{tabular}{|l|l|l|l|}
\hline \multicolumn{4}{|l|}{ Prelude in C major } \\
\hline \multicolumn{4}{|l|}{ One-part form,two-movement phrase } \\
\hline & a & a' & coda \\
\hline bar count & 8 & 16 & 10 \\
\hline C & D9 & T & T \\
\hline
\end{tabular}

Form 2: Prelude in a minor tune structure.

\begin{tabular}{|c|c|c|c|c|}
\hline \multicolumn{5}{|c|}{ Prelude in a minor } \\
\hline & prelude & a & b & C (expanded) \\
\hline bar count & 2 & 5 & 6 & 10 \\
\hline e & t & G:T & a:Vii/v & a:t \\
\hline
\end{tabular}


Form 3: Prelude in e minor tune structure.

\begin{tabular}{|c|c|c|}
\hline \multicolumn{3}{|c|}{ Prelude in e minor } \\
\hline \multicolumn{2}{|c|}{ One-part form Two-movement phrase } \\
\hline & $\mathrm{a}$ & $\mathrm{a}^{\prime}$ \\
\hline bar count & 12 & 13 \\
\hline $\mathrm{a}$ & $\mathrm{D} 7$ & $\mathrm{t}$ \\
\hline
\end{tabular}

Chopin did not compose his preludes at random and his principle was to incorporate more musical elements into a limited number of piano miniatures, and the proverb that a sparrow is small is a good illustration of a prelude. Each prelude has its own complete thematic image. Some preludes even epitomize a larger work.

\section{Harmonic thinking}

The first Prelude in $\mathrm{C}$ major: $\mathrm{C}$ major runs through the entire work, the first phrase is tonally stable and the harmonic progression is an overall outline of $\mathrm{T}$ to $\mathrm{D}$. The second phrase is twice as long as the first, moving mainly in the key of C major, with the phrases D34/TSVI-TSV, DVII7/D-K46 appearing. The addition of a chromatic upward progression in the melodic voice and an upward progression in the bass voice (example 1) not only serve to expand the phrase, but this linear approach to the bass progression also brings a sense of mystery to the music. The coda is superimposed on the second phrase, and there is a repetition of the thematic melodic fragment in the coda, with the bass of the left-hand dominant chord continuing throughout, further stabilizing the key of C major.

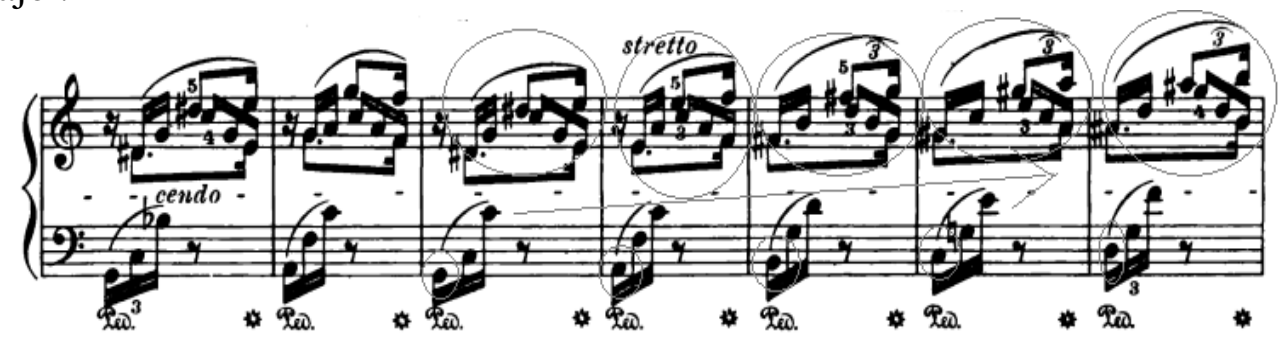

Score example 1: Prelude in C major, bars 14-20.

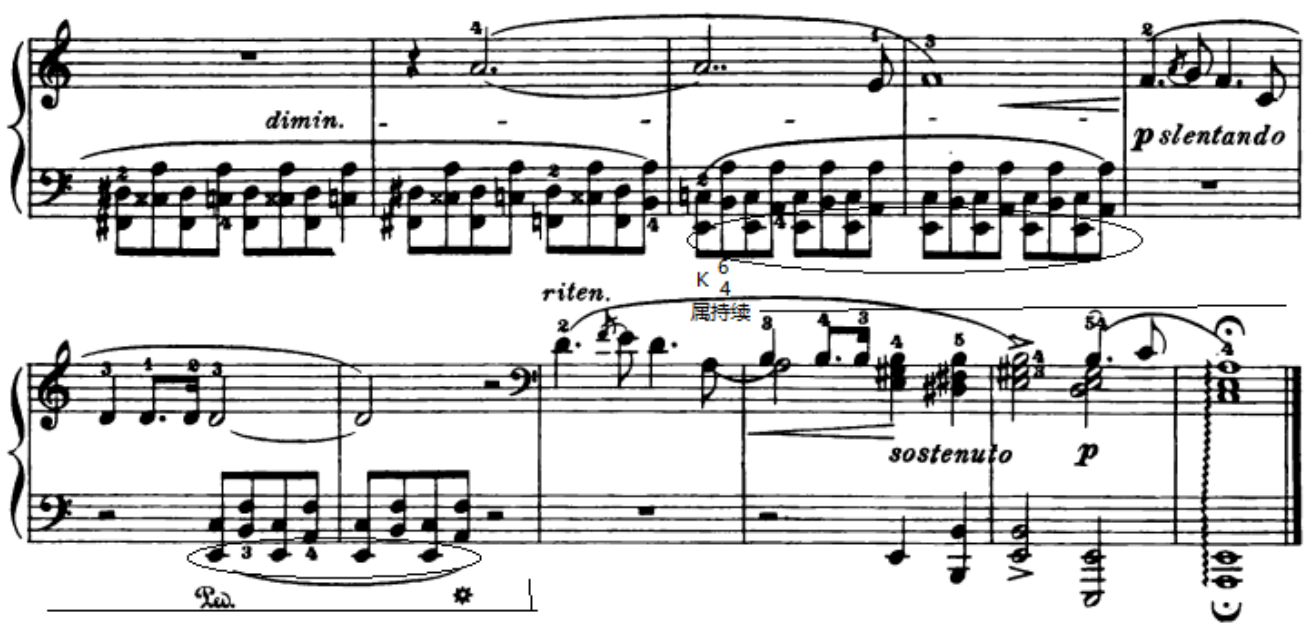

Score example 2: Prelude in A minor, bars 13-23.

Second Prelude in A Minor: this prelude is marked A minor, but the piece enters from the key of E minor, the genus of A minor. The overall tonal layout of e-G-b-a can be seen in the fact that this 
piece wanders in the key of proximity from the beginning and does not return to the dominant until the end of the second phrase. In order to clarify the key of A minor, the piece makes use of a large number of genus sustained notes in the closing phrase (example 2 of the score). The most characteristic feature of this piece is that the melody develops in motivic elongation changes, upward 5ths and 4ths imitating the development, all the time intoning and singing like a song, with breaths and pauses, while the harmonies of the left hand accompaniment go on endlessly, without breaths, until they finally terminate in A minor.

The fourth Prelude in E minor: this work is in E minor throughout, but the opening first phrase uses four consecutive seventh chord progressions after the t6 chord (example 3) to draw the music tonally into ambiguity and to accentuate Chopin's compositional style. The second phrase is a variation and development of the first, and the harmonic tension is heightened from the first, which serves to set up the climax of the work. Apart from the extensive use of coloratura chords, the basic harmonic layout of the work is still relatively traditional (T-D-DVII-T), which means that we can still be clear about the tonal modality of the work. It is worth noting that bass linear progressions are a characteristic of Chopin's compositions, and this piece shows it in spades. The almost identical bass linear progression of the two phrases (G-B,G-\#A) suggests a transposition and the anticipation of a new key, but Chopin does not end on the new key, but rather clarifies the dominant after a brief gap (rest) (Example 4).

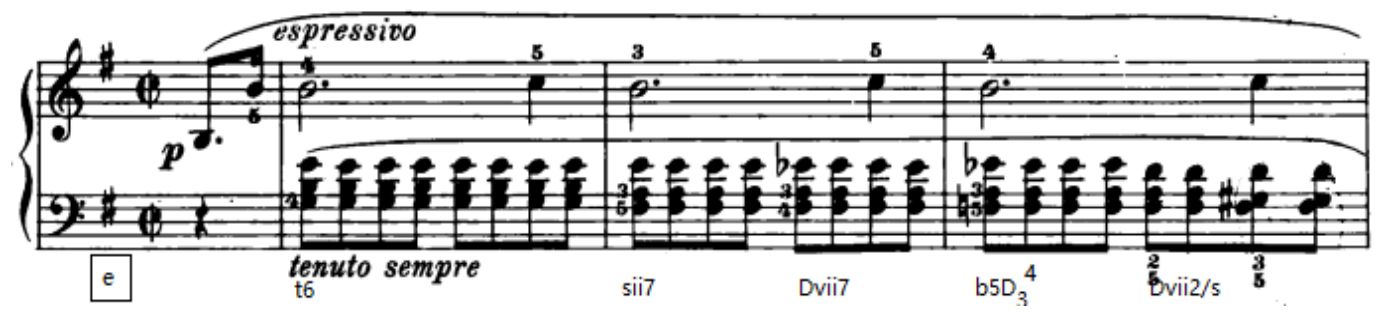

Score example 3: Prelude in e minor, bars 1-3.

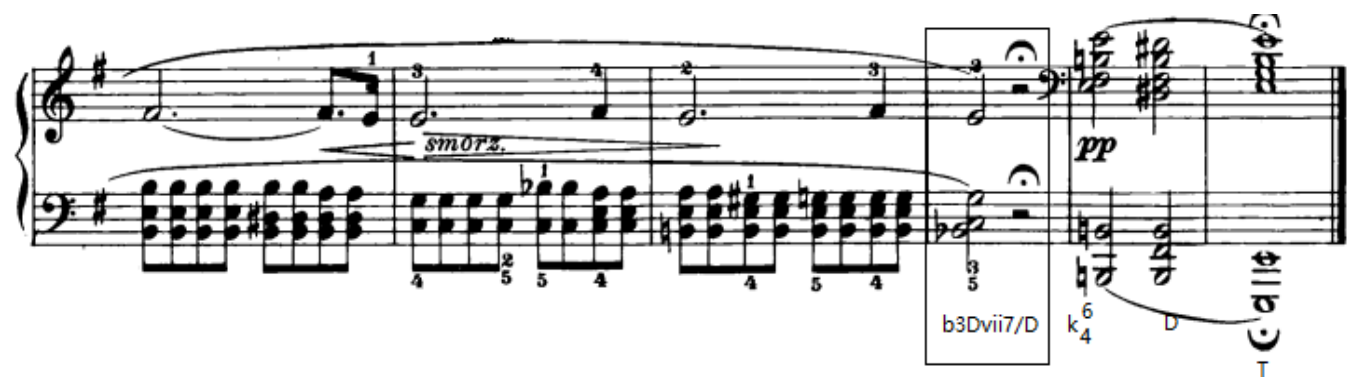

Score example 4: Prelude in e minor bars 20-25.

A careful harmonic analysis of the three works shows that the use of dominant and genus chords in the prelude phrases is minimal and only serves as a harmonic framework. In the course of the prelude, the subordinate chords are expanded and the harmonic function of the subgenus chords is matured, which is a good reflection of the "liberal" harmonic thinking of Romanticism. The use of bass chromatic progressions and sustained basses in the preludes remains Chopin's usual compositional technique for increasing tension and driving the mood of the music. This use is also evident in Scriabin's early preludes.

\section{Analysis of the evolution}

Tonal music is generally studied using the traditional methods of analysis that we use. From the structure of the piece to the harmony to the melody and so on, dissecting it step by step from horizontal to vertical. By the 1970s, the Austrian music theorist Heinrich Schenker's diagrammatic 
approach led the way and became synonymous with tonal music. Schenker introduced the concept of Structural Levels, which grouped the different levels of music into Background, Middle ground, and Foreground. However, his analysis diagram is still rather obscure and difficult to understand, and one has to learn the set of theories completely to understand. With the advent of the era of big data, computers have introduced two-dimensional spectral analysis means, so that the analysis map seems to be able to see the characteristics of the work more intuitively. The national research team of the Shenyang Normal University and the Shenyang Conservatory of Music has proposed for the first time a new method of analysis of polyphonic music, namely the two-dimensional analysis of musical levels. The team has made a two-dimensional score for some of Chopin's Twenty-four Preludes, see the two-dimensional score of the thematic parts of the first, second and fourth pieces (Example 5). It is possible to analyze and study the works from a new perspective, offering similarly more possibilities for future performances.
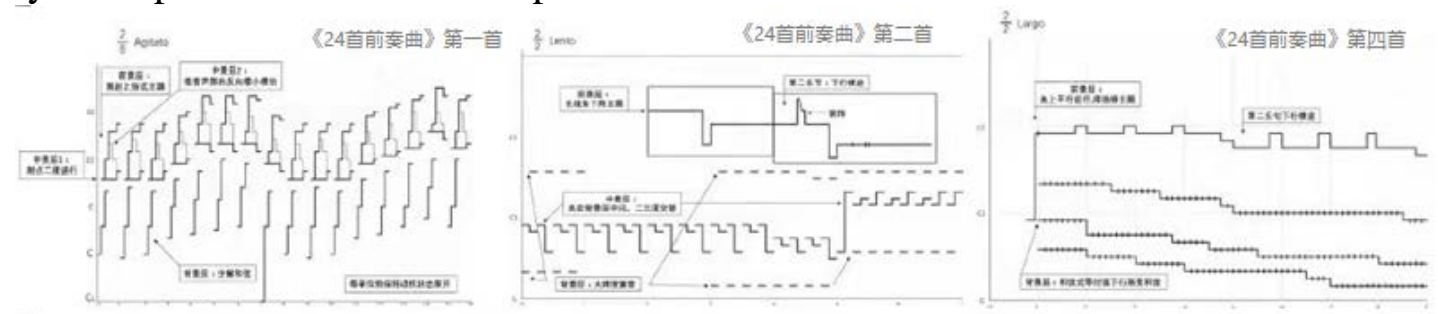

Example 5 of the score.

\section{Conclusion}

Chopin's Twenty-four Preludes are not improvisations, nor are they untitled music, although the content of each one is very clear and has been given a graphic name by later generations. For example, the fourth "Suffocation", the eighth "Despair" and the fifteenth "Raindrop". This set of preludes was also the first choice of many pianists in their golden years of recording. I remember Martha Argerich's version of the Fourth, which is so distinctive, with its strong tempo contrasts adding to the colour of the work. In an interview, Mr. Foucault spoke of changing the original group of pedals in the sixteenth Prelude in b-flat minor to a continuous long pedal in Chopin's manuscript, to seek dissonance, intensity, and fearful sound. In the thirteenth Prelude in \#F major, the 6/4 time is crossed out in favor of 3/2 time (all currently published versions are in 6/4), no longer wanting a long melodic line, but highlighting the syncopated rhythmic effect. Chopin's imagination, his creativity, was indeed very unique, and he lent that uniqueness to this set of preludes as well.

The Twenty-four Preludes are one of the masterpieces that highlight Chopin's style. This set of works not only continues the stylistic characteristics of the Romantic period, but also sees the shadow of the Impressionist style, through the study of this set of works, the preludes as a whole have a certain improvisation, the harmonic development is also a big breakthrough than before, and the melody has more national characteristics. It is of great value from both an analytical and a performance point of view.

\section{References}

[1] Yao Henglu, China, Analysis of Twentieth Century Composition Techniques, Shanghai Music Publishing House, February, 2001.

[2] Regina Smenyanka Poland, How to Play Chopin, China Federation of Literary Press, translated by Liang Quanbing and Yao Manhua, January, 2004.

[3] Wu Shih-kai, China, The Art of Harmony, Shanghai Music Publishing House, October, 2004.

[4] Wang Xu China "A two-dimensional mapping hierarchy analysis of Chopin's Preludes", Art Education, 2018, Vol. 22, No. 100-101. 
[5] Zhang Hui,China, "The creation of a two-dimensional analysis of musical levels", Art Education, 2018, Vol.18, No.58-60.

[6] He Tianyuan, China, “An analysis of the music and performance techniques of Chopin's Twenty-four preludes”, Master's thesis, Xi'an Conservatory of Music Academy, 2020.

[7] Yang Fengxiang, China, "A Study of the Harmonic Technique in Chopin's Prelude No. 4”, Comedy World (Second Half), 2020, Vol. 03, No. 26-27.

[8] Zou Runnan, China, “An Analysis of the First Twelve Preludes in Chopin's Twenty-four Preludes and Composition Techniques”, Northern Music, 2018, Vol.03, No.82, 143.

[9] Xiao Yao, China, "An analysis of the development of the piano prelude genre” , Chinese Literary Artists, 2020, Vol.03, No.32-33.

[10] Ling Gan, China, “An Exploration of Chopin's Twenty-four Preludes as a Whole”, Northern Music ,2019,Vol.7, No.78-80. 